\title{
Overview of the Status of Organizational and Financial Management of the Austrian Industrial Holding
}

Marko Šarić ${ }^{1 *}$, Bojan Rosi ${ }^{2}$

${ }^{1} \mathrm{Ph} . \mathrm{D}$ Candidat, Faculty of Logistics, University of Maribor, Slovenia, Europa

${ }^{2}$ Professor, dr. sc. Faculty of Logistics, University of Maribor, Slovenia, Europa

DOI: $10.36347 /$ sjahss.2020.v08i11.001

| Received: 09.10.2020 | Accepted: 18.10.2020 | Published: 20.11.2020

*Corresponding author: Marko Šarić

\section{Abstract}

The paper presents the history and development of the Austrian industrial holding. The authors also deal with the Act governing the operations of the Austrian holding, as well as the organizational structure, portfolio value, dividends, and privatization revenues. Finally, the importance of the Austrian industrial holding for the Republic of Austria is summarized. The Austrian holding also plays an important role in international cooperation, especially when it comes to the OECD principles of corporate governance.

Keywords: Austrian holding, organizational and financial management, organizational structure.

Copyright $(\mathcal{C} 2020$ The Author(s): This is an open-access article distributed under the terms of the Creative Commons Attribution 4.0 International License (CC BY-NC 4.0) which permits unrestricted use, distribution, and reproduction in any medium for non-commercial use provided the original author and source are credited.

\section{INTRODUCTION}

The Austrian holding company was founded in 1967 as ÖIAG or Österreichische Industrieverwaltungs - GmbH and transformed in 1970 into a joint stock company (Österreichische Industrieverwaltungs-AG). It was established to centralize the administration and represent the Austrian government's interest in nationalized companies.

The holding company with the companies in which it held shares formed the group until 1993, when it was divided with the task of privatizing most of the companies in the group. In 2015, ÖIAG was transformed from a joint stock company into a limited liability company and changed its name to ÖBIB, i.e. the Österreichische Bundes- und Industriebeteiligungsholding. The change was made to make it easier for the holding to buy shares in companies, for which it is directly responsible to the Austrian Ministry of Finance. ÖBIB oversees all investments of state-owned companies in the Austrian provinces, has the right to take over new shares (acquisitions are allowed), reports directly to the Ministry of Finance and protects the ownership interests of the Austrian state. The CEO of a holding company does not sit on the supervisory boards of companies that are under full or partial state control as was the case before the transformation. ÖBIB does not have its own supervisory board but has a kind of advisory body (under the control of the state) that nominates members of the board for companies. such as, among others, GKB (100\%), IMIb (100\%), Finbag (100\%), OMV (31.5\% of shares), Telekom Austria (28.4\% of shares), Casinos Austria $(33,2 \%)$ and the Austrian Post $(52.9 \%$ of state-owned shares)] [1,2].

\section{Austrian Holding - history}

The Austrian industrial holding [3] was founded in 1967 as ÖIAG or Österreichische Industrieverwaltungs $-\mathrm{GmbH}$ and transformed in 1970 into a joint stock company (Österreichische Industrieverwaltungs-AG). It was established to centralize administration and represent the country's interest in nationalized companies. The holding company with the companies in which it held shares formed the group until 1993, when it was divided with the task of privatizing most of the companies in the group.

Later, in 2015, ÖIAG was transformed from a joint stock company into a limited liability company and changed its name to ÖBIB, i.e. the Österreichische Bundes- und Industrial maintenance holding. As we pointed out earlier, the change was made to make it easier for the holding to buy stakes in companies, for which it is directly responsible to the state finance ministry. ÖBIB supervises all Austrian state investments in state-owned or partly state-owned companies, has the right to take over new shares (acquisitions are allowed), reports directly to the 
Ministry of Finance and protects the ownership interests of the state of Austria.

A holding company (German: Holding Dachgesellschaft) is a legal entity that holds or permanently participates in the ownership of other, legally independent, companies.

There are different types of holding companies; when a company operates exclusively by taking possession and participating in the ownership and management of other companies, the same business portfolio it is about a homogeneous holding company. In case the company has other activities, it is a mixedheterogeneous holding company. If the goal of the holding company is ownership of an industrial character, it is an industrial holding company.

When a company's goal is to invest funds, it is called a financial holding company. Such companies participate with their share capital in the share capital of another company, which in turn can participate part of its assets in the share capital of third companies, etc. In this way the holding company has an impact on the operations of all these companies (sister companies, subsidiaries, grandchildren) who are legally independent but economically dependent on the holding. Thus, networks of several dozen (in some cases more than a hundred) companies are formed, controlled by one interest group.

"The historical development of ÖBIB [4, 5] and its predecessors is very long and dates to the postwar years and covers the period of the Second World War. On July 26, 1946, the Austrian National Council passed the first nationalization law to prevent "German" companies from falling into the hands of the Soviet occupation forces. In total, these "German companies" accounted for one-fifth of Austria's value added and included the country's three largest banks, the entire metal and coal sector, the entire oil and refining sector, and all important companies in heavy industries.

The nationalized industry was then run directly by the government. In 1967, it was decided to transfer all rights to the shares of the nationalized companies to the newly established Österreichische Industrieverwaltungs GesmbH (ÖIG). As early as 1970, ÖIG became a joint stock company (Aktiengesellschaft) - ÖIAG and underwent extensive restructuring.

Some of ÖIAG's companies began reporting losses in the early 1980s. As a result, ÖIAG was restructured in 1986: the conglomerates were divided and merged into new subsidiaries, which were to be rehabilitated by privatization proceeds and then privatized on the stock exchange. In 1993, the subsidiaries were dissolved and a revised version of the ÖIAG Act required the ÖIAG to "surrender the shares of the industrial companies within a reasonable time (...).

The ÖIAG [6, 7] Act of 2000 marked another milestone. Its purpose was to force privatization and sell companies for the best possible returns, while preserving Austrian interests. Privatization funds of $€$ 6.3 billion (cumulative between 2000 and 2012) were used to reduce ÖBIB's debt. In addition, the new law gave ÖIAG the institutions independence from its owner, the Republic of Austria, by creating a selfregulatory supervisory board.

The revision of the ÖIAG Act 2000 - the ÖBIB Act - was adopted in 2015, giving the company a new strategic direction for national and international development. The priority is to preserve the interests of the owners and to manage and monitor the shares of the federal state. The company name and legal form of ÖIAG was changed to ÖBIB Österreichische Bundesund Industriebeteiligungen $\mathrm{GmbH}$. ÖBIB does not have its own supervisory board. Instead, it is necessary to report regularly to the Minister of Finance on important issues and development, who further reports to the Chancellor and Deputy Chancellors.

ÖBIB's Austrian Holding Act entered into force on 19 March 2015, followed by the transformation of Österreichische Industrieholding AG (ÖIAG) [joint stock company] into $\mathrm{GmbH}$ [limited liability company], which operates under the name Österreichische Bundes-

und Industriebeteiligungen $\mathrm{GmbH}$.

The law formulates specific goals and tasks set by the federal government, as follows [8]:

- ÖBIB must represent the interests of the federal government as the owner of strategically important shares.

- $\quad$ ÖBIB aims to preserve and increase the value of important shares of the federal government, as well as to promote the advantages of the Republic of Austria as a destination for trade, business and research, in creating and maintaining employment in Austria

- The aim of the new legislation is to manage and monitor shares with an emphasis on responsible, sustainable, and long-term value creation, which is in the best interests of all Austrian taxpayers

- ÖBIB effectively and professionally implements the strategic decisions of the owners

- The Nomination Committee, which operates in accordance with the highest professional standards and sets strict selection criteria, appoints the members of the supervisory boards of the companies of which ÖBIB holds a stake. 
Benefits for the federal government and Austrian taxpayers are at the heart of all ÖBIB's efforts.

\section{Area of organizational activity}

ÖBIB currently has a $52.85 \%$ stake in Österreichische Post, a $31.5 \%$ stake in OMV and a $28.42 \%$ stake in Telekom Austria, as well as a $33.24 \%$ stake in Casinos Austria AG. ÖBIB is also the sole owner of FIMBAG Finanzmarktbeteiligung AG (now in liquidation), GKB-Bergbau GmbH, IMIB Immobilienund Industriebeteiligungen $\mathrm{GmbH}$ and SchoellerBleckmann $\mathrm{GmbH}$ and holds a $32.53 \%$ stake in APK Pensionskasse AG.

ÖBIB's strategic task is to effectively manage the shares entrusted to it by the federal government:

1. Investment management - includes the holding, management, and execution of ownership interests as well as the preparation of decisions of the board of companies in which ÖBIB has a stake. This means that ÖBIB protects its influence through the shares entrusted to it, through contracts and agreements with third parties (e.g. trade union agreements) or by maintaining at least $25 \%$ of the ownership stake plus one share.

2. Privatization Management - describes the professional handling of privatization projects, for which there is an explicit order from the federal government. In such cases, ÖBIB privatizes the companies to maximize the benefits for the Republic of Austria.

3. Acquisition of shares - is also one of the tasks of ÖBIB. However, an explicit order from the federal government is needed.

4. Preservation of ownership interests - implies the preparation and implementation of shareholder meetings and decisions, but also the support of supervisory boards appointed by the federal government.
5. Advising the Republic of Austria - in the role of ÖBIB as a know-how carrier and service company that prepares strategic information, prepares complex decisions and acts as an expert with excellent know-how in the business and capital markets.

6. Counseling of the Republic of Austria ÖBIB serves as a knowledge center. The holding provides strategic information, expert advice and prepares the federal government for complex financial decisions with its extensive knowledge of the market, business, and capital.

\section{Organizational management of the Austrian industrial holding}

The ÖBIB 2015 Act changes the organizational structure, tasks, and decision-making process. The Austrian parliament operates at the highest level and sets the general direction of the holding by passing a law. The federal government makes decisions on privatization and investment management, which can lead to specific tasks for ÖBIB. The Republic of Austria is a $100 \%$ owner of the holding. ÖBIB is obliged to report to the Minister of Finance on important issues, who informs the Chancellor and Deputy Chancellor. The Nomination Committee, which serves as an advisory board to ÖBIB GmbH under a special law, is responsible for selecting the members of the supervisory board appointed by the federal government. The Nomination Committee consists of four members appointed by the federal government for one legislative term based on a joint recommendation of the Chancellor and the Deputy. Two of the four members must be current federal ministers or state secretaries. The other two members are businesspeople or executives from the business or public sector with many years of experience. They must, without any doubt, be able to perform their duties independently of their own interests. They remain in office at least until a new federal government is formed. ÖBIB also works closely with its union partners $[9,10]$.

Table-1: Ownership share

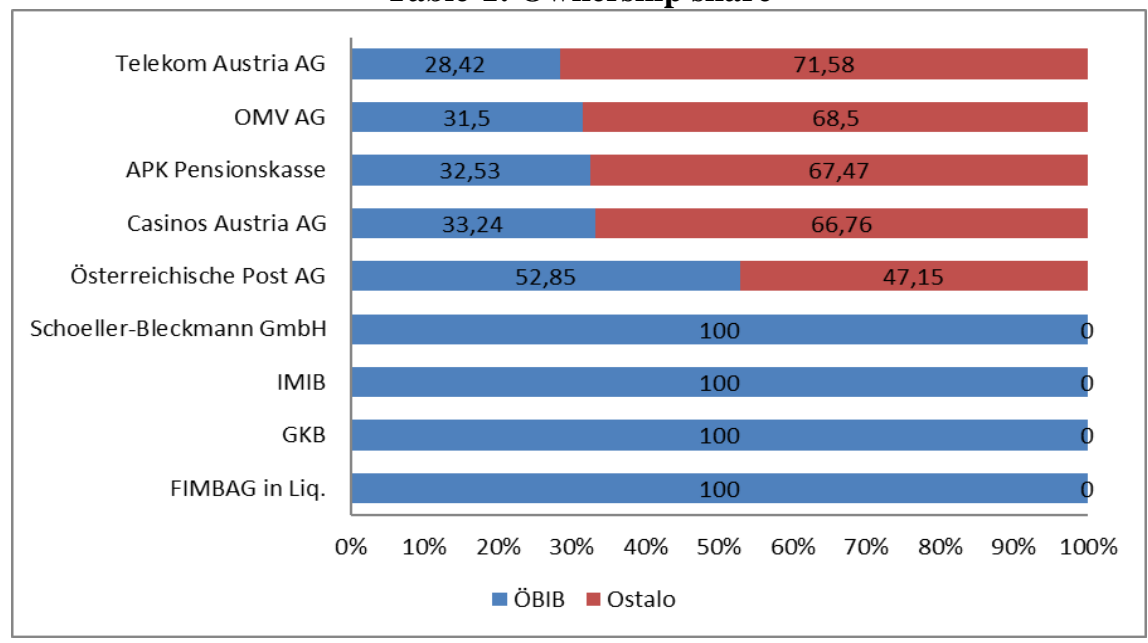


The holding currently has a stake in nine companies, three of which are OMV, Telekom Austria and Österreichische Post, as well as Casinos Austria AG, APK Pensionskasse, FIMBAG, GKB, IMIB und Schoeller-Bleckmann GmbH [11].

ÖIAG had a stake in the following companies:

1. Austria Metall AG (AMAG).

2. Austria Mikro Systeme International AG.

3. Austria Technologie \& Systemtechnik AG.

4. Austrian Airlines (in 2009 sold to Lufthansa AG).

5. Böhler-Uddeholm AG.

6. Dorotheum.
7. Flughafen Wien AG.

8. Österreichische Staatsdruckerei.

9. Print Media Austria AG.

10. Schoeller-Bleckmann Stahlwerke.

11. Siemens AG Österreich.

12. SGP Verkehrstechnik.

13. Tabakregie (früher Austria Tabak).

14. VA Technologie.

15. Voestalpine.

Due to the sale of these companies, large protests were organized as well as discontent by politicians, unions, and councils [14].

Table-2: Portfolio value

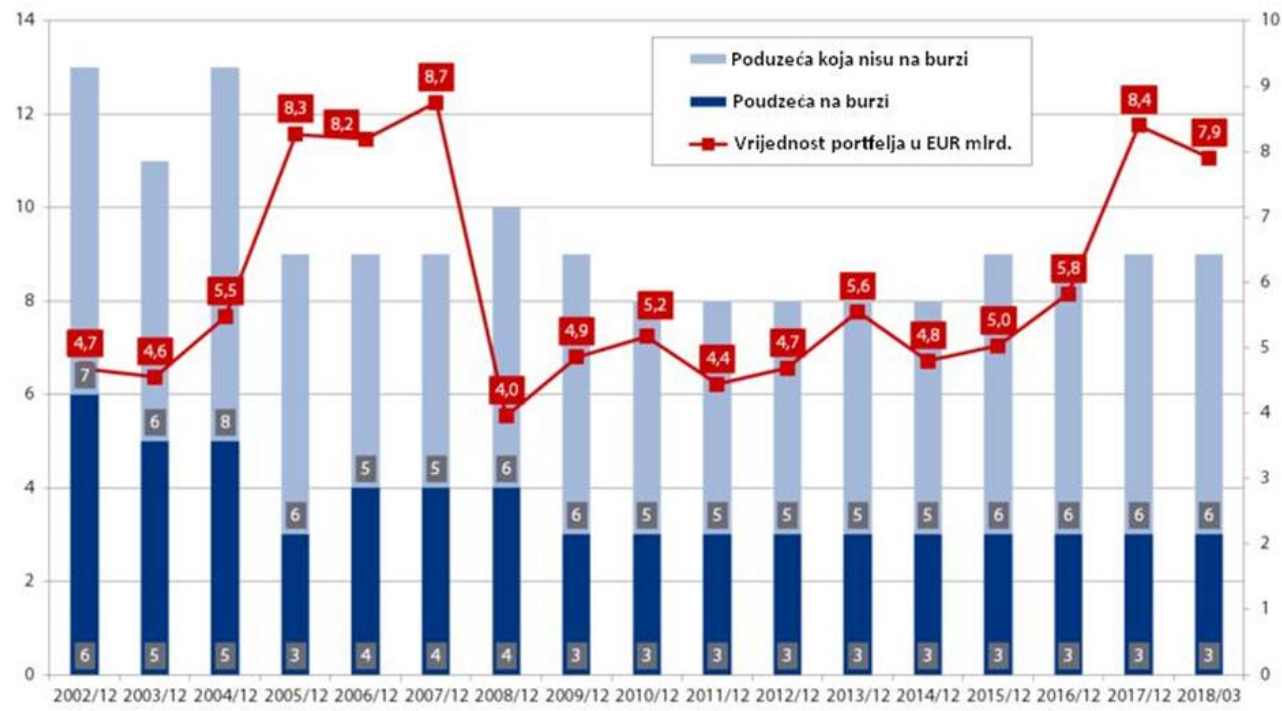

Current portfolio value: approx. EUR 7.9 billion [15].

Table-3: Dividends

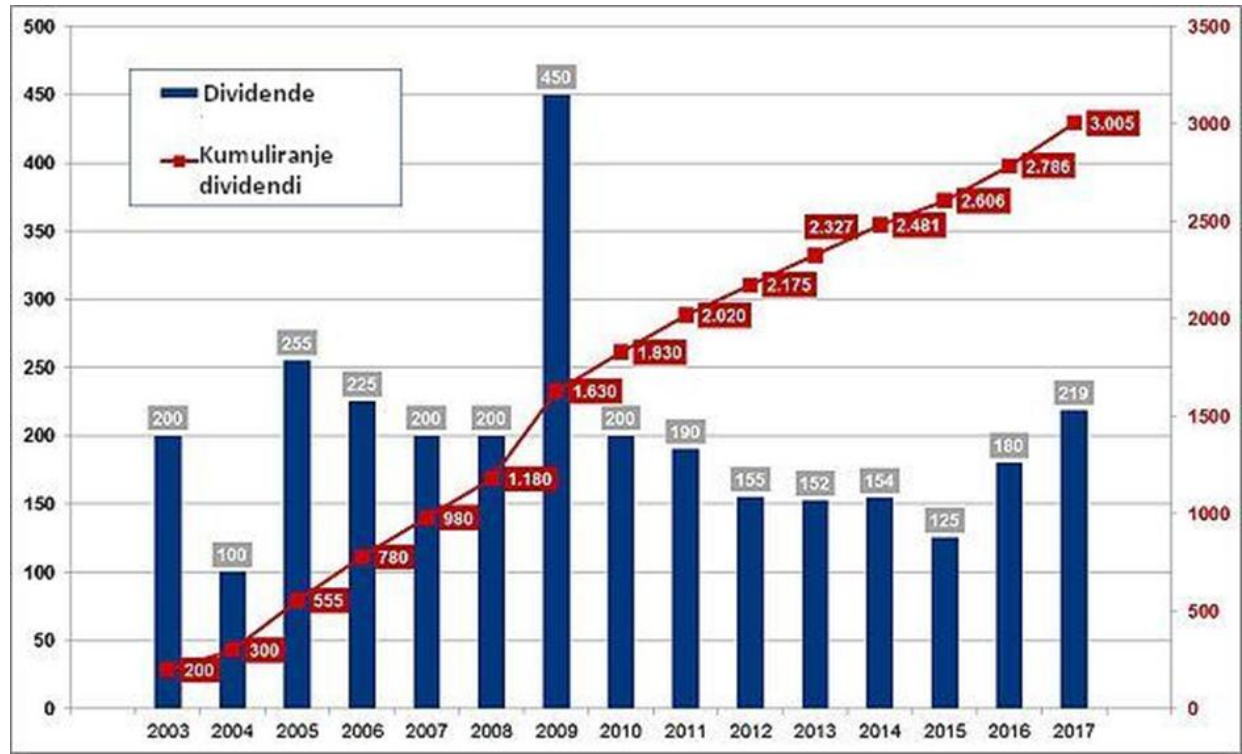

Payment of ÖBIB dividend to Austria, since 2003 in the amount of EUR 3.0 billion 
Table-4: Privatization revenues

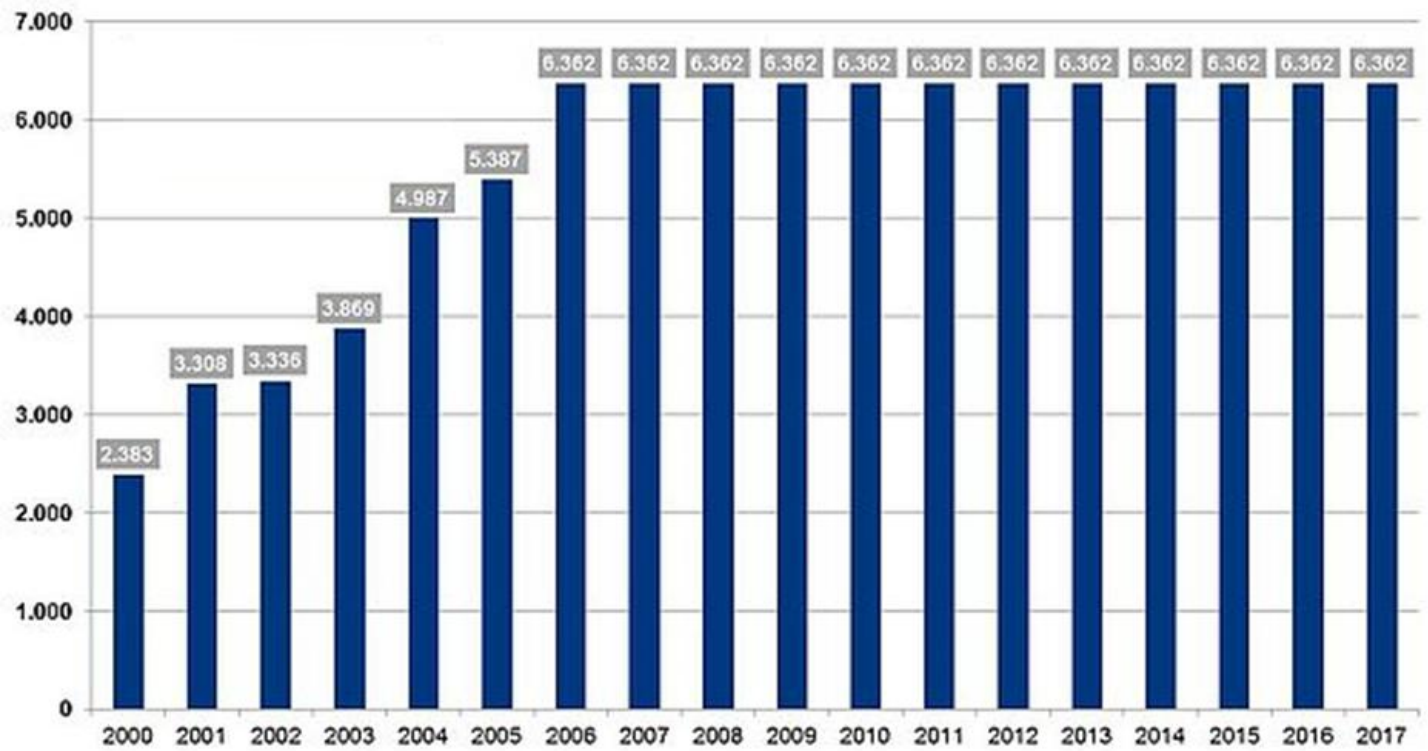

Cumulative privatization revenues amounted to 6.3 billion euros between 2000 and 2017 [16].

The importance of the Austrian industrial holding for the Republic of Austria is extremely important. As a key Austrian shareholder and representative of the federal government, ÖBIB plays a strategic role in strengthening Austria's position as a hub for business. ÖBIB is a strong shareholder, because with its three stated shares it makes approx. $20 \%$ of the market capitalization of the ATX index. It also possesses a high portfolio value. Austrian taxpayers have ownership stakes in companies worth approx. $€$ 7.9 billion through ÖBIB. Between 2003 and 2017, ÖBIB paid a dividend of $€ 3.0$ billion to the federal government. ÖBIB is one of the most important employers. The companies in which ÖBIB has a stake provide around 35,500 jobs in Austria, and their suppliers provide an additional approx. 75,000 jobs. In addition to being an important employer, ÖBIB is also a strong customer in the Austrian market. 97\% of orders from OMV, Telekom Austria and Post are awarded to small and medium-sized enterprises. In addition, ÖBIB companies purchase products and services from 15,000 SMEs. In this way, they effectively stimulate the Austrian market. ÖBIB's international cooperation consists of numerous contacts around the world as part of its efforts to manage the federal government's ownership stakes as best as possible, as well as to protect Austria's position as a center of business and research.

Her contacts include international Share- and Stakeholders as well as capital market experts. ÖBIB is also represented by the OECD Corporate Governance Committee's Working Party on State Ownership and Privatization Practices, where it is involved in the further development of the OECD Guidelines on
Corporate Governance of State-Owned Enterprises [17].

\section{CONCLUSION}

In 2016, there was a lot of talk in the EU member state about the Austrian holding model. The then president of the HDZ, Tomislav Karamarko, outlined the possibilities of uniting all public companies into a Holding, following the example of the Austrian model, which proved to be good and efficient. However, no changes have taken place. The Austrian holding model has proven to be very efficient. Austria has thus placed state-owned companies under the control of a strategic body for privatization and restructuring, today it manages nine large companies and has paid around 3 billion euros in dividends since 2013. ÖBIB is a strong shareholder and makes approx. $20 \%$ of the market capitalization of the ATX index. Austrian taxpayers have ownership stakes in companies worth approx. 7.9 billion euros. ÖBIB has an important role to play in strengthening Austria's position as a business hub.

\section{LITERATURE}

1. Što sve sadrži austrijski model koji bi uveo HDZ, pristup 1.6.2018. https://www.tportal.hr/biznis/clanak/sto-svesadrzi-austrijski-model-koji-bi-uveo-hdz20151007.

2. Tipurić, Darko prof. dr. sc. - Budućnost poduzeća u državnom vlasništvu u modernoj ekonomiji, pristup 29.5.2018 https://konferencije.lider.media/buducnost-javnihpoduzeca-2016/wpcontent/uploads/sites/76/2015/05/2016_NOVO1004-Bez-B-Dubrovnik-LIDER.pdf.

3. Leksikon - Holding društvo, pristup 20.5.2018. http://www.poslovni.hr/leksikon/holding-drustvo1408. 
4. Geschichte, pristup 24.5.2018. http://www.oebib.gv.at/auftrag/geschichte/.

5. Geschichte, pristup 24.5.2018. https://de.wikipedia.org/wiki/Österreichische_Bun des-_und_Industriebeteiligungen.

6. ÖBIB Gesetz, pristup 30.5.2018. http://www.oebib.gv.at/auftrag/oebib-gesetz/.

7. Državni zakon o reorganizaciji pravnih odnosa austrijskog holdinga, pošte i telekomunikacijskih društava.

8. Aufgaben, pristup 28.5.2018. http://www.oebib.gv.at/auftrag/aufgaben/.

9. Struktur, pristup 19.5.2018 http://www.oebib.gv.at/organisation/struktur/.

10. Nominierungskomitee, pristup 19.5.2018. http://www.oebib.gv.at/organisation/nominierungs komitee/.
11. Beteiligung, pristup 29.5.2018. http://www.oebib.gv.at/beteiligungen/.

12. Beteiligung, pristup 29.5.2018. https://de.wikipedia.org/wiki/\%C3\%96sterreichisc he_Bundes-_und_Industriebeteiligungen.

13. Portofolio-Wert, pristup 20.5.2018. http://www.oebib.gv.at/fakten/portfolio-wert/

14. Dividende, pristup 20.5.2018. http://www.oebib.gv.at/fakten/dividenden/.

15. Privatisierungserlöse, pristup 20.5.2018. http://www.oebib.gv.at/fakten/privatisierungserloe se/.

16. Bedeutung für Österreich, pristup 28.5.2018. http://www.oebib.gv.at/auftrag/bedeutung-fueroesterreich/.

17. Weltweit vernetzt, pristup 18.5.2018. http://www.oebib.gv.at/auftrag/internationalekooperation/. 